\title{
IMPLEMENTASI SMALL GROUP DISCUSSION DAN COLLABORATIVE LEARNING UNTUK MENINGKATKAN PRESTASI BELAJAR MAHASISWA PROGRAM STUDI PENDIDIKAN AKUNTANSI IKIP PGRI MADIUN
}

\author{
Nur Wahyuning Sulistyowati \\ Pendidikan Akuntansi IKIP PGRI MADIUN \\ laurafredikson@yahoo.co.id
}

\begin{abstract}
ABSTRAK
Penelitian tindakan kelas bertujuan untuk meningkatkan prestasi belajar mahasiswa program studi pendidikan akuntansi IKIP PGRI Madiun. Pengumpulan data dilakukan melalui observasi dan dokumentasi. Penelitian ini menggunakan analisis deskriptif kualitatif dengan menggunakan model Kemmis dan Taggart. Model Kemmis dan Taggart dilaksanakan melalui empat tahapan yaitu perencanaan, pelaksanaan, observasi dan refleksi. Hasil penelitian ini menemukan telah terjadi peningkatan prestasi belajar mahasiswa program studi pendidikan akuntansi IKIP PGRI Madiun dengan metode model pembelajaran Small Group Discussion Dan Collaborative Learning. Dibuktikan dengan meningkatnya prestasi belajar mahasiswa yaitu dengan nilai IPK A dan B dengan kategori lulus, serta penggunaan waktu dan materi presentasi mahasiswa menjadi lebih baik dibadingkan sebelumnya, aktif dan berkompetisi yang sehat antar kelompok pada saat presentasi.
\end{abstract}

Kata kunci: Small Group Discussion, Collaborative Learning, Prestasi Belajar

\section{PENDAHULUAN}

Kemajuan teknologi yang berpengaruh terhadap kehidupan sosial, ekonomi, politik, dan budaya yang bergerak dinamis secara langsung akan mempengaruhi masa depan lulusan mahasiswa. Masa depan lulusan mahasiswa pendidikan akuntansi menjadi pusat perhatian yang serius bagi Program Studi Pendidikan Akuntansi IKIP PGRI Madiun. Kompetensi lulusan sarjana di dunia kerja dibagi dua aspek. Pertama, aspek teknis berhubungan dengan latar belakang keahlian atau keahlian yang diperlukan di dunia kerja (hard skill). Kedua, aspek non teknis (soft skill) mencakup motivasi, adaptasi, komunikasi, kerjasama dalam tim, pemecahan persoalan, manajemen stress dan kepemimpinan. Kompetensi lulusan tidak saja dinilai dari hard skill tetapi juga dinilai soft skill.

Dalam UU No. 20/2003 tetang Sistem Pendidikan Nasional, dinyatakan bahwa pembelajaran adalah proses interaksi peserta didik dengan pendidik dan sumber belajar pada satu lingkungan belajar. Interaksi terjadi antara mahasiswa dengan dosen. Dalam interaksi yang berpusat pada mahasiswa (student centered learning) terjadi perubahan yang dialami mahasiswa dalam empat ranah, yang disebut dengan ranah kognitif, yaitu kemampuan yang berkenaan dengan pengetahuan, pikiran; ranah afekif, yaitu kemampuan yang mengutamakan perasaan, emosi yang berbeda berdasarkan penalaran; ranah psikomotorik, yaitu kemampuan yang mengutamakan keterampilan jasmani, dan ranah kooperatif, yaitu kemampuan untuk bekerja sama.

Adanya perubahan kebijakan dalam bidang pendidikan yaitu pengembangan kurikulum berbasis KKNI, dan perbaikan SDM IKIP PGRI Madiun yang linear dengan program studi, serta adanya aturan baru mengenai pendidikan yang diatur Permenristek Dikti No. 44 tahun 2015 tentang Standar Nasional Pendidikan Tinggi (SNPT). Kebijakan institusi IKIP PGRI Madiun untuk menerapkan pembelajaran berbasis SCL (Student Centered 
Learning) dengan menggunakan instrument penilaian meliputi aspek kognitif, afektif, dan psikomotor. Tujuan pembelajaran telah tercermin dalam visi program studi pendidikan akuntansi yaitu menjadi pusat pengembangan pendidikan akuntansi yang unggul di tingkat nasional yang menghasilkan lulusan yang cerdas, kompetitif, dan bermartabat berbasis ilmu pengetahuan dan teknologi serta memiliki jiwa kewirausahaan pada tahun 2020.

Tu'u (2004:75) menyatakan bahwa prestasi merupakan hasil yang dicapai seseorang ketika mengerjakan tugas atau kegiatan tertentu. Prestasi belajar adalah penguasaan pengetahuan atau keterampilan yang dikembangkan oleh mata pelajaran yang lazimnya ditunjukkan dengan nilai tes atau angka nilai yang diberikan guru. Adapun indikator dalam penelitian ini yaitu prestasi belajar akuntansi adalah nilai IPK Mahasiswa.

Small group discussion adalah proses pembelajaran dengan melakukan diskusi kelompok kecil tujuannya agar peserta didik memiliki keterampilan memecahkan masalah terkait materi pokok dan persoalan yang dihadapi dalam kehidupan sehari-hari. Small group discussion juga berarti proses penglihatan dua atau lebih individu yang berinteraksi secara global dan saling berhadapan muka mengenai tujuan atau sasaran yang sudah tertentu melalui tukar menukar informasi, mempertahankan pendapat atau pemecahan masalah. Sedangkan pembelajaran kolaboratif dapat menyediakan peluang untuk menuju pada kesuksesan praktekpraktek pembelajaran. Sebagai teknologi untuk pembelajaran (technology for instruction), pembelajaran kolaboratif melibatkan partisipasi aktif para siswa dan meminimisasi perbedaan-perbedaan antar individu.

Dalam mencapai lulusan yang berkompetensi dengan input mahasiswa yang memiliki latar belakang pendidikan yang heterogen diantaranya dari lulusan SMA dengan jurusan (IPA dan IPS), SMK (Teknik, Kimia, Farmasi, Tata Rias, Perkantoran, Akuntansi, Pemasaran), dan lain-lain. Di mana terdapat budaya mahasiswa yang meminjam buku modul kakak tingkat untuk disalin kembali jawabannya, tanpa mempelajari dan memahami dalam proses belajar. Kecanggihan teknologi sebagai contoh HP untuk mengambil gambar jawaban dari teman untuk disalin sebagai jawaban mahasiswa yang bersangkutan. Kebijakan institusi dengan pedoman penilaian yaitu nilai D mahasiswa tidak lulus dan harus mengulang. Oleh sebab itu, mahasiswa berorientasi mendapatkan nilai yang bagus dengan berbagai cara supaya tidak mendapat nilai $\mathrm{D}$, bukan berorientasi pada ilmu yang harus diperoleh atau didapatkan dalam kuliah. Dengan demikian penulis mengkaji penelitian yang berjudul "Implementasi Small Group Discussion Dan Collaborative Learning Untuk Meningkatkan Prestasi Belajar Mahasiswa Program Studi Pendidikan Akuntansi IKIP PGRI Madiun". Small Group Discussion dan Collaborative Learning merupakan bagian dari metode model pembelajaran Student Center Learning (SCL).

\section{TINJAUAN PUSTAKA}

\section{Metode Pembelajaran Small Group Discussion}

Small group discussion adalah proses pembelajaran dengan melakukan diskusi kelompok kecil tujuannya agar peserta didik memiliki keterampilan memecahkan masalah terkait materi pokok dan persoalan yang dihadapi dalam kehidupan sehari-hari. Small group discussion juga berarti proses penglihatan dua atau lebih individu yang berinteraksi secara global dan saling berhadapan muka mengenai tujuan atau sasaran yang sudah tertentu melalui tukar menukar informasi, mempertahankan pendapat atau pemecahan masalah. Small group 
discussion sebagaimana pembelajaran kelompok lainnya memiliki unsur-unsur yang saling terkait, yakni:

1. Saling ketergantungan positif (positive interdependence).

Cooperative learning menghendaki adanya ketergantungan positif saling membantu dan saling memberikan motivasi sehingga ada interaksi diantara mahasiswa.

2. Akuntabilitas individual (individual accountability)

Small group discussion menuntut adanya akuntabilitas individual yang mengukur penguasaan bahan belajar tiap anggota kelompok, dan diberi balikan tentang prestasi belajar anggota-anggotanya sehingga mereka saling mengetahui rekan yang memerlukan bantuan. Berbeda dengan kelompok tradisional, akuntabilitas individual sering diabaikan sehingga tugas-tugas sering dikerjakan oleh sebagian anggota. Dalam small group discussion, mahasiswa harus bertanggungjawab terhadap tugas yang diemban masingmasing anggota.

3. Tatap muka (face to face interaction)

Small group discussion menuntut semua anggota dalam kelompok belajar dapat saling tatap muka sehingga mereka dapat berdialog tidak hanya dengan guru atau dosen tapi juga bersama dengan teman. Interaksi semacam itu memungkinkan anak-anak atau mahasiswa menjadi sumber belajar bagi sesamanya. Hal ini diperlukan karena mahasiswa sering merasa lebih mudah belajar dari sesamanya dari pada dari dosen.

4. Ketrampilan Sosial (Social Skill)

Unsur ini menghendaki mahasiswa untuk dibekali berbagai ketrampilan sosial seperti tenggang rasa, sikap sopan kepada teman, mengkritik ide, berani mempertahankan pikiran logis, tidak mendominasi yang lain, mandiri, dan berbagai sifat lain yang bermanfaat dalam menjalin hubungan antar pribadi tidak hanya diasumsikan tetapi secara sengaja diajarkan.

5. Proses Kelompok (Group Processing)

Proses ini terjadi ketika tiap anggota kelompok mengevaluasi sejauh mana mereka berinteraksi secara efektif untuk mencapai tujuan bersama. Kelompok perlu membahas perilaku anggota yang kooperatif dan tidak kooperatif serta membuat keputusan perilaku mana yang harus diubah atau dipertahankan.

\section{Tujuan Metode Small Group}

Sebagai metode belajar, belajar kelompok diskusi atau small group discussion mengandung tujuan yang ingin dikembangkan. Tujuan diskusi atau small group discussion antara lain :

1. Agar mahasiswa berbincang-bincang untuk memecahkan masalah-masalah sendiri.

2. Agar mahasiswa berbincang-bincang mengenai masalah-masalah apa saja yang berhubungan dengan kehidupan mereka sehari-hari, dengan kehidupan mereka di sekolah atau perguruan tinggi, dengan sesuatu yang terjadi di lingkungan sekitar mereka dan sebagainya.

3. Agar mahasiswa berbincang-bincang mengenai pelajaran di kelas dengan maksud saling mengoreksi pemahaman mereka atas pelajaran yang diterimanya, agar masing-masing anggota memperoleh pemahaman yang lebih baik. 
Sedangkan menurut Ismail SM tujuan penerapan strategi ini adalah agar peserta didik memiliki keterampilan memecahkan masalah terkait materi pokok dan persoalan yang dihadapi dalam kehidupan sehari-hari.

Metode small group discussion diskusi mungkin tidak efektif untuk menyajikan informasi baru dimana peserta didik atau mahasiswa sudah dengan sendirinya termotivasi. Tetapi diskusi tampaknya sangat cocok ketika guru atau dosen ingin melakukan hal-hal dibawah ini:

1. Membantu peserta didik belajar berfikir dari sudut pandang suatu subjek bahasan dengan memberi mereka praktek berpikir.

2. Membantu peserta didik mengevaluasi logika serta bukti-bukti bagi posisi dirinya atau posisi yang lain

3. Memberi kesempatan pada peserta didik untuk memformulasikan penerapan suatu prinsip.

4. Membantu peserta didik menyadari akan suatu problem dan menformulasikannya dengan menggunakan informasi yang diperoleh dari bacaan atau ceramah.

5. Menggunakan bahan-bahan dari anggota lain dalam kelompoknya.

6. Memperoleh penerimaan bagi informasi atau teori yang mengkomentari cerita rakyat atau kepercayaan peserta didik terdahulu.

7. Mengembangkan motivasi untuk belajar yang lebih jauh.

8. Memperoleh feedback yang cepat tentang seberapa jauh suatu tujuan tercapai.

Sistem pembelajaran yang baik seharusnya dapat membantu mahasiswa mengembangkan diri secara optimal serta mampu mencapai tujuan-tujuan belajarnya. Meskipun proses belajar mengajar tidak dapat sepenuhnya berpusat pada mahasiswa (pupil centered instruction) seperti pada sistem pendidikan terbuka, tetapi perlu diingat bahwa pada hakekatnya mahasiswalah yang harus belajar.

Dengan demikian, proses belajar mengajar perlu berorientasi pada kebutuhan dan kemampuan mahasiswa, misalnya dengan pendekatan "inquiry-discovery learning". Kegiatan-kegiatan yang dilaksanakan di sini harus dapat memberikan pengalaman belajar yang menyenangkan dan berguna baginya. Dosen perlu memberikan bermacam-macam situasi belajar yang memadai untuk materi yang disajikan, dan menyesuaikannya dengan kemampuan dan karakteristik serta gaya belajar mahasiswa. Sebagai konsekuensi logisnya, dosen dituntut harus kaya metodologi mengajar sekaligus terampil menerapkannya, tidak monoton dan variatif dalam melaksanakan pembelajaran.

\section{Peran Guru/Dosen Dalam Metode Small Group}

Sesuai dengan pengertian mengajar yaitu menciptakan suasana yang mengembangkan inisiatif dan tanggung jawab belajar mahasiswa. Maka sikap dosen hendaknya:

1. Terbuka mau mendengarkan pendapat mahasiswa.

2. Membiasakan peserta didik untuk mendengarkan bila dosen atau mahasiswa lain berbicara.

3. Menghargai perbedaan pendapat.

4. "Mentolelir" salah dan mendorong untuk memperbaiki.

5. Menumbuhkan rasa percaya diri mahasiswa.

6. Memberi umpan balik terhadap hasil kerja dosen.

7. Tidak terlalu cepat membantu mahasiswa. 
8. Tidak kikir untuk memuji atau menghargai.

9. Tidak mentertawakan pendapat atau hasil karya mahasiswa sekalipun kurang berkualitas.

10. Mendorong mahasiswa untuk tidak takut salah dan berani menanggung resiko.

Dalam pengajaran yang dimiliki dalam metode small group discussion, maka posisi dan peran dosen harus menempatkan diri sebagai:

1. Pemimpin belajar, artinya merencanakan, mengorganisasi, melaksanakan dan mengontrol kegiatan belajar mahasiswa.

2. Fasilitator belajar artinya memberikan kemudahan-kemudahan mahasiswa dalam melakukan kegiatan belajarnya misal, menyediakan sumber dan alat belajar, menyediakan waktu belajar yang cukup, memberi bantuan, menunjukkan jalan keluar pemecahan masalah, menengahi perdebatan pendapat dan sebagainya.

3. Moderator belajar artinya sebagai pengatur arus belajar mahasiswa, dosen menampung persoalan yang diajukan oleh mahasiswa dan mengembalikan lagi persoalan tersebut kepada yang lain, untuk dijawab dan dipecahkan. Jawaban tersebut dikembalikan kepada penannya atau kepada kelas untuk dinilai benar salahnya.

4. Motivator belajar sebagai pendorong agar mahasiswa mau melakukan kegiatan belajar.

5. Evaluator artinya sebagai penilai yang obyektif dan komprehensif, dosen berkewajiban memantau, mengawasi, proses belajar peserta didik dan hasil belajar yang dicapainya.

\section{Langkah-Langkah dalam Metode Small Group}

Langkah-langkah penerapan metode small group discussion diantaranya :

1. Bagi kelas menjadi beberapa kelompok kecil (maksimal 5 murid) dengan menunjuk ketua dan sekretaris.

2. Berikan soal studi kasus (yang dipersiapkan oleh dosen) sesuai dengan Capaian Pembelajaran (CP) \& Kemampuan Akhir Yang Direncanakan.

3. Instruksikan setiap kelompok untuk mendiskusikan jawaban soal tersebut.

4. Pastikan setiap anggota berpartisipasi aktif dalam diskusi.

5. Instruksikan setiap kelompok melalui juru bicara yang ditunjuk menyajikan hasil diskusinya dalam forum kelas.

6. Klarifikasi, penyimpulan dan tindak lanjut (Dosen).

\section{Metode Pembelajaran Collaborative Learning}

Pembelajaran kolaboratif dapat menyediakan peluang untuk menuju pada kesuksesan praktek-praktek pembelajaran. Sebagai teknologi untuk pembelajaran (technology for instruction), pembelajaran kolaboratif melibatkan partisipasi aktif para mahasiswa dan meminimisasi perbedaan-perbedaan antar individu. Pembelajaran kolaboratif telah menambah momentum pendidikan formal dan informal dari dua kekuatan yang bertemu, yaitu :

1. Realisasi praktek, bahwa hidup di luar kelas memerlukan aktivitas kolaboratif dalam kehidupan di dunia nyata.

2. Menumbuhkan kesadaran berinteraksi sosial dalam upaya mewujudkan pembelajaran bermakna.

Ide pembelajaran kolaboratif bermula dari perpsektif filosofis terhadap konsep belajar. Untuk dapat belajar, seseorang harus memiliki pasangan. Pada tahun 1916, John Dewey, menulis sebuah buku "Democracy and Education" yang isinya bahwa kelas merupakan 
cermin masyarakat dan berfungsi sebagai laboratorium untuk belajar tentang kehidupan nyata. Pemikiran Dewey yang utama tentang pendidikan (Jacob et al., 1996), adalah:

1. Siswa hendaknya aktif, learning by doing.

2. Belajar hendaknya didasari motivasi intrinsik.

3. Pengetahuan adalah berkembang, tidak bersifat tetap.

4. Kegiatan belajar hendaknya sesuai dengan kebutuhan dan minat siswa.

5. Pendidikan harus mencakup kegiatan belajar dengan prinsip saling memahami dan saling menghormati satu sama lain, artinya prosedur demokratis sangat penting.

6. Kegiatan belajar hendaknya berhubungan dengan dunia nyata dan bertujuan mengembangkan dunia tersebut.

Metode kolaboratif didasarkan pada asumsi-asumsi mengenai siswa proses belajar sebagai berikut (Smith \& MacGregor, 1992):

1. Belajar itu aktif dan konstruktif

Untuk mempelajari bahan pelajaran, siswa harus terlibat secara aktif dengan bahan itu.

Siswa perlu mengintegrasikan bahan baru ini dengan pengetahuan yang telah dimiliki sebelumnya. Siswa membangun makna atau mencipta sesuatu yang baru yang terkait dengan bahan pelajaran.

2. Belajar itu bergantung konteks

Kegiatan pembelajaran menghadapkan siswa pada tugas atau masalah menantang yang terkait dengan konteks yang sudah dikenal siswa. Siswa terlibat langsung dalam penyelesaian tugas atau pemecahan masalah itu.

3. Siswa itu beraneka latar belakang

Para siswa mempunyai perbedaan dalam banyak hal, seperti latar belakang, gaya belajar, pengalaman, dan aspirasi. Perbedaan-perbedaan itu diakui dan diterima dalam kegiatan kerjasama, dan bahkan diperlukan untuk meningkatkan mutu pencapaian hasil bersama dalam proses belajar.

4. Belajar itu bersifat sosial

Proses belajar merupakan proses interaksi sosial yang di dalamnya siswa membangun makna yang diterima bersama.

Menurut Piaget dan Vigotsky, strategi pembelajaran kolaboratif didukung oleh adanya tiga teori, yaitu :

1. Teori Kognitif

Teori ini berkaitan dengan terjadinya pertukaran konsep antar anggota kelompok pada pembelajaran kolaboratif sehingga dalam suatu kelompok akan terjadi proses transformasi ilmu pengetahuan pada setiap anggota.

2. Teori Konstruktivisme Sosial

Pada teori ini terlihat adanya interaksi sosial antar anggota yang akan membantu perkembangan individu dan meningkatkan sikap saling menghormati pendapat semu anggota semua kelompok.

3. Teori Motivasi

Teori ini teraplikasi dalam struktur pembelajaran kolaboratif karena pembelajaran tersebut akan memberikan lingkungan yang kondusif bagi siswa untuk belajar, menambah 
keberanian anggota untuk memberi pendapat dan menciptakan situasi saling memerlukan pada seluruh anggota dalam kelompok.

Piaget dengan konsepnya "active learning" berpendapat bahwa para siswa belajar lebih baik jika mereka berpikir secara kelompok, menurut pikiran mereka maka oleh sebab itu menjelaskan sebuah pekerjaan lebih baik menampilkan di depan keras. Piaget juga berpendapat bila suatu kelompok aktif klompok tersebut akan melibatkan yang lain untuk berpikir bersama, sehingga dalam belajar lebih menarik (Smith, B.L. and Mac Gregor, 2004).

\section{Tujuan Model Kolaborasi}

Dalam penerapan pembelajaran kolaborasi, terdapat pergeseran peran si belajar (MacGregor, 2005):

1. Dari pendengar, pengamat dan pencatat menjadi pemecah masalah yang aktif, pemberi masukan dan suka diskusi.

2. Dari persiapan kelas dengan harapan yang rendah atau sedang menjadi ke persiapan kelas dengan harapan yang tinggi.

3. Dari kehadiran pribadi atau individual dengan sedikit resiko atau permasalahan menjadi kehadiran publik dengan banyak resiko dan permasalahan.

4. Dari pilihan pribadi menjadi pilihan yang sesuai dengan harapan komunitasnya.

5. Dari kompetisi antar teman sejawat menjadi kolaborasi antar teman sejawat.

6. Dari tanggung jawab dan belajar mandiri, menjadi tanggung jawab kelompok dan belajar saling ketergantungan.

7. Dahulu melihat guru dan teks sebagai sumber utama yang memiliki otoritas dan sumber pengetahuan sekarang guru dan teks bukanlah satu-satunya sumber belajar. Banyak sumber belajar lainnya yang dapat digali dari komunitas kelompoknya.

Gokhale mendefinisikan bahwa "collaborative learning" mengacu pada metode pengajaran di mana siswa dalam satu kelompok yang bervariasi tingkat kecakapannya bekerjasama dalam kelompok kecil yang mengarah pada tujuan bersama. Pengertian kolaborasi sendiri yaitu:

Keohane berpendapat bahwa kolaborasi adalah bekerja bersama dengan yang lain, kerja sama, bekerja dalam bagian satu team, dan di dalamnya bercampur di dalam satu kelompok menuju keberhasilan bersama.

Patel berpendapat bahwa kolaborasi adalah suatu proses saling ketergantungan fungsional dalam mencoba untuk keterampilan koordinasi, to coordinate skills, tools, and rewards.

Dari pengertian kolaborasi yang diungkapkan oleh berbagai ahli tersebut, dapat disimpulkan bahwa pengertian belajar kolaborasi adalah suatu strategi pembelajaran di mana para mahasiswa dengan variasi yang bertingkat bekerjasama dalam kelompok kecil ke arah satu tujuan. Dalam kelompok ini para mahasiswa saling membantu antara satu dengan yang lain. Jadi situasi belajar kolaboratif ada unsur ketergantungan yang positif untuk mencapai kesuksesan.

Belajar kolaboratif menuntut adanya modifikasi tujuan pembelajaran dari yang semula sekedar penyampaian informasi menjadi konstruksi pengetahuan oleh individu melalui belajar kelompok. Dalam belajar kolaboratif, tidak ada perbedaan tugas untuk masing-masing 
individu, melainkan tugas itu milik bersama dan diselesikan secara bersama tanpa membedakan percakapan belajar mahasiswa.

Dari uraian di atas, kita bisa mengetahui hal yang ditekankan dalam belajar kolaboratif yaitu bagaimana cara agar mahasiswa dalam aktivitas belajar kelompok terjadi adanya kerjasama, interaksi, dan pertukaran informasi.

Selain itu, dapat disimpulkan bahwa tujuan dari pembelajaran kolaboratif adalah sebagai berikut :

1. Memaksimalkan proses kerjasama yang berlangsung secara alamiah di antara para mahasiswa.

2. Menciptakan lingkungan pembelajaran yang berpusat pada mahasiswa, kontekstual, terintegrasi, dan bersuasana kerjasama.

3. Menghargai pentingnya keaslian, kontribusi, dan pengalaman mahasiswa dalam kaitannya dengan bahan pelajaran dan proses belajar.

4. Memberi kesempatan kepada mahasiswa menjadi partisipan aktif dalam proses belajar.

5. Mengembangkan berpikir kritis dan keterampilan pemecahan masalah.

6. Mendorong eksplorasi bahan pelajaran yang melibatkan bermacam-macam sudut pandang.

7. Menghargai pentingnya konteks sosial bagi proses belajar.

8. Menumbuhkan hubungan yang saling mendukung dan saling menghargai di antara para mahasiswa, dan di antara mahasiswa dan dosen.

9. Membangun semangat belajar sepanjang hayat.

\section{Langkah-Langkah Pembelajaran Kolaboratif}

Berikut ini langkah-langkah pembelajaran kolaboratif:

1. Para mahasiswa dalam kelompok menetapkan tujuan belajar dan membagi tugas sendirisendiri.

2. Semua mahasiswa dalam kelompok membaca, berdiskusi, dan menulis.

3. Kelompok kolaboratif bekerja secara bersinergi mengidentifikasi, mendemontrasikan, meneliti, menganalisis, dan memformulasikan jawaban-jawaban tugas atau masalah dalam LKS atau masalah yang ditemukan sendiri.

4. Setelah kelompok kolaboratif menyepakati hasil pemecahan masalah, masing-masing mahasiswa menulis laporan sendiri-sendiri secara lengkap.

5. Guru/Dosen menunjuk salah satu kelompok secara acak (selanjutnya diupayakan agar semua kelompok dapat giliran ke depan) untuk melakukan presentasi hasil diskusi kelompok kolaboratifnya di depan kelas, mahasiswa pada kelompok lain mengamati, mencermati, membandingkan hasil presentasi tersebut, dan menanggapi. Kegiatan ini dilakukan selama lebih kurang 20-30 menit.

6. Masing-masing mahasiswa dalam kelompok kolaboratif melakukan elaborasi, inferensi, dan revisi (bila diperlukan) terhadap laporan yang akan dikumpulan.

7. Laporan masing-masing mahasiswa terhadap tugas-tugas yang telah dikumpulkan, disusun perkelompok kolaboratif.

8. Laporan mahasiswa dikoreksi, dikomentari, dinilai, dikembalikan pada pertemuan berikutnya, dan didiskusikan. 


\section{Macam-Macam Pembelajaran Kolaboratif}

Ada banyak macam pembelajaran kolaboratif yang pernah dikembangkan oleh para ahli maupun praktisi pendidikan, teristimewa oleh para ahli Student Team Learning pada John Hopkins University. Tetapi hanya sekitar sepuluh macam yang mendapatkan perhatian secara luas, yaitu :

\section{Learning Together}

Dalam metode ini kelompok-kelompok sekelas beranggotakan siswa-siswa yang beragam kemampuannya. Tiap kelompok bekerjasama untuk menyelesaikan tugas yang diberikan oleh guru atau dosen. Satu kelompok hanya menerima dan mengerjakan satu set lembar tugas. Penilaian didasarkan pada hasil kerja kelompok.

2. Teams-Games-Tournament (TGT)

Setelah belajar bersama kelompoknya sendiri, para anggota suatu kelompok akan berlomba dengan anggota kelompok lain sesuai dengan tingkat kemampuan masingmasing. Penilaian didasarkan pada jumlah nilai yang diperoleh kelompok.

3. Group Investigation (GI)

Semua anggota kelompok dituntut untuk merencanakan suatu penelitian beserta perencanaan pemecahan masalah yang dihadapi. Kelompok menentukan apa saja yang akan dikerjakan dan siapa saja yang akan melaksanakannya berikut bagaimana perencanaan penyajiannya di depan forum kelas. Penilaian didasarkan pada proses dan hasil kerja kelompok.

4. Academic-Constructive Controversy (AC)

Setiap anggota kelompok dituntut kemampuannya untuk berada dalam situasi konflik intelektual yang dikembangkan berdasarkan hasil belajar masing-masing, baik bersama anggota sekelompok maupun dengan anggota kelompok lain. Kegiatan pembelajaran ini mengutamakan pencapaian dan pengembangan kualitas pemecahan masalah, pemikiran kritis, pertimbangan, hubungan antarpribadi, kesehatan psikis dan keselarasan. Penilaian didasarkan pada kemampuan setiap anggota maupun kelompok mempertahankan posisi yang dipilihnya.

5. Jigsaw Proscedure (JP)

Dalam bentuk pembelajaran ini, anggota suatu kelompok diberi tugas yang berbeda-beda tentang suatu pokok bahasan. Agar setiap anggota dapat memahami keseluruhan pokok bahasan, tes diberikan dengan materi yang menyeluruh. Penilaian didasarkan pada ratarata skor tes kelompok.

6. Student Team Achievement Divisions (STAD)

Para mahasiswa dalam suatu kelas dibagi menjadi beberapa kelompok kecil. Anggotaanggota dalam setiap kelompok saling belajar dan membelajarkan sesamanya. Fokusnya adalah keberhasilan seorang akan berpengaruh terhadap keberhasilan kelompok dan demikian pula keberhasilan kelompok akan berpengaruh terhadap keberhasilan individu mahasiswa. Penilaian didasarkan pada pencapaian hasil belajar individual maupun kelompok.

7. Complex Instruction (CI)

Metode pembelajaran ini menekankan pelaksanaan suatu proyek yang berorientasi pada penemuan, khususnya dalam bidang sains, matematika dan pengetahuan sosial. Fokusnya adalah menumbuhkembangkan ketertarikan semua anggota kelompok terhadap pokok 
bahasan. Metode ini umumnya digunakan dalam pembelajaran yang bersifat bilingual (menggunakan dua bahasa) dan diantara para mahasiswa yang sangat heterogen. Penilaian didasarkan pada proses dan hasil kerja kelompok.

8. Team Accelerated Instruction (TAI)

Bentuk pembelajaran ini merupakan kombinasi antara pembelajaran kooperatif/kolaboratif dengan pembelajaran individual. Secara bertahap, setiap anggota kelompok diberi soal-soal yang harus mereka kerjakan sendiri terlebih dulu. Setelah itu dilaksanakan penilaian bersama-sama dalam kelompok. Jika soal tahap pertama telah diselesaikan dengan benar, setiap mahasiswa mengerjakan soal-soal tahap berikutnya. Namun jika seorang mahasiswa belum dapat menyelesaikan soal tahap pertama dengan benar, ia harus menyelesaikan soal lain pada tahap yang sama. Setiap tahapan soal disusun berdasarkan tingkat kesukaran soal. Penilaian didasarkan pada hasil belajar individual maupun kelompok.

9. Cooperative Learning Stuctures (CLS)

Dalam pembelajaran ini setiap kelompok dibentuk dengan anggota dua siswa (berpasangan). Seorang siswa bertindak sebagai tutor dan yang lain menjadi tutee. Tutor mengajukan pertanyaan yang harus dijawab oleh tutee. Bila jawaban tutee benar, ia memperoleh poin atau skor yang telah ditetapkan terlebih dulu. Dalam selang waktu yang juga telah ditetapkan sebelumnya, kedua siswa yang saling berpasangan itu berganti peran.

10. Cooperative Integrated Reading and Composition (CIRC)

Model pembelajaran ini mirip dengan TAI. Sesuai namanya, model pembelajaran ini menekankan pembelajaran membaca, menulis dan tata bahasa. Dalam pembelajaran ini, para siswa/mahasiswa saling menilai kemampuan membaca, menulis dan tata bahasa, baik secara tertulis maupun lisan di dalam kelompoknya.

Keterampilan yang dibutuhkan oleh peserta yang berpartisipasi dalam model pembelajaran kolaboratif adalah:

1. Pembentukan kelompok

2. Bekerja dalam satu kelompok

3. Pemecahan masalah kelompok

4. Manajemen perbedaan kelompok

Menurut Reid (2004) dalam menggembangkan collaborative learning ada lima tahapan yang harus dilakukan, yaitu:

1. Engagement

Pada tahap ini, pengajar melakukan penilaian terhadap kemampuan, minat, bakat dan kecerdasan yang dimiliki oleh masing-masing siswa. Lalu, siswa dikelompokkan yang di dalamnya terdapat siswa terpandai, siswa sedang, dan siswa yang rendah prestasinya.

2. Exploration

Setelah dilakukan pengelompokkan, lalu pengajar mulai memberi tugas, misalnya dengan memberi permasalahan agar dipecahkan oleh kelompok tersebut. Dengan masalah yang diperoleh, semua anggota kelompok harus berusaha untuk menyumbangkan kemampuan berupa ilmu, pendapat ataupun gagasannya. 
3. Transformation

Dari perbedaan kemampuan yang dimiliki oleh masing-masing siswa, lalu setiap anggota saling bertukar pikiran dan melakukan diskusi kelompok. Dengan begitu, siswa yang semula mempunyai prestasi rendah, lama kelamaan akan dapat menaikkan prestasinya karena adanya proses transformasi dari siswa yang memiliki prestasi tinggi kepada siswa yang prestasinya rendah.

4. Presentation

Setelah selesai melakukan diskusi dan menyusun laporan, lalu setiap kelompok mempresentasikan hasil diskusinya. Pada saat salah satu kelompok melakukan presentasi, maka kelompok lain mengamati, mencermati, membandingkan hasil presentasi tersebut, dan menanggapi.

5. Reflection

Setelah selesai melakukan presentasi, lalu terjadi proses Tanya-jawab antar kelompok. Kelompok yang melakukan presentasi akan menerima pertanyaan, tanggapan ataupun sanggahan dari kelompok lain. Dengan pertanyaan yang diajukan oleh kelompok lain, anggota kelompok harus bekerjasama secara kompak untuk menanggapi dengan baik.

Brandt (2004) menekankan adanya lima elemen dasar yang dibutuhkan agar kerjasama dalam proses pembelajaran dapat sukses, yaitu :

1. Possitive interdependence (saling ketergantungan positif)

Yaitu siswa harus percaya bahwa mereka adalah proses belajar bersama dan mereka peduli pada belajar siswa yang lain. Dalam pembelajaran ini setiap siswa harus merasa bahwa ia bergantung secara positif dan terikat dengan antarsesama anggota kelompoknya dengan tanggung jawab menguasai bahan pelajaran dan memastikan bahwa semua anggota kelompoknya pun menguasainya. Mereka merasa tidak akan sukses bila siswa lain juga tidak sukses.

2. Verbal, face to face interaction (interaksi langsung antarsiswa)

Yaitu hasil belajar yang terbaik dapat diperoleh dengan adanya komunikasi verbal antarsiswa yang didukung oleh saling ketergantungan positif. Siswa harus saling berhadapan dan saling membantu dalam pencapaian tujuan belajar. Siswa juga harus menjelaskan, berargumen, elaborasi, dan terikat terhadap apa yang mereka pelajari sekarang untuk mengikat apa yang mereka pelajari sebelumnya.

3. Individual accountability (pertanggungjawaban individu)

Yaitu setiap kelompok harus realis bahwa mereka harus belajar. Agar dalam suatu kelompok siswa dapat menyumbang, mendukung dan membantu satu sama lain, setiap siswa dituntut harus menguasai materi yang dijadikan pokok bahasan. Dengan demikian setiap anggota kelompok bertanggung jawab untuk mempelajari pokok bahasan dan bertanggung jawab pula terhadap hasil belajar kelompok.

4. Social skills (keterampilan berkolaborasi)

Yaitu keterampilan sosial siswa sangat penting dalam pembelajaran. Siswa dituntut mempunyai keterampilan berkolaborasi, sehingga dalam kelompok tercipta interaksi yang dinamis untuk saling belajar dan membelajarkan sebagai bagian dari proses belajar kolaboratif. Siswa harus belajar dan diajar kepemimpian, komunikasi, kepercayaan, membangun dan keterampilan dalam memecahkan konflik. 
5. Group processing (keefektifan proses kelompok)

Yaitu kelompok harus mampu menilai kebaikan apa yang mereka kerjakan secara bersama dan bagaimana mereka dapat melakukan secara lebih baik. Siswa memproses keefektifan kelompok belajarnya dengan cara menjelaskan tindakan mana yang dapat menyumbang belajar dan mana yang tidak serta membuat keputusan-keputusan tindakan yang dapat dilanjutkan atau yang perlu diubah. Tiga pola pengelompokkan, yaitu:

a. The two-person group (tutoring)

Yaitu satu orang ditugasi mengajar yang lain. Jadi, siswa dapat berperan sebagai pengajar yang disebut tutor, sedangkan siswa yang lain disebut tutee.

b. The small group (interactive recitation; discussion)

Adalah cara penyampaian bahan pelajaran di mana guru memberi kesempatan kepada siswa untuk mengumpulkan pendapat, membuat kesimpulan atau menyusun berbagai alternative pemecahan masalah.

c. Small or large group (recitation)

Yaitu suatu metode mengajar dan pengajar memberikan tugas untuk mempelajari sesuatu kepada pembelajar, kemudian melaporkan hasilnya. Tugas-tugas yang diberikan oleh pengajar dapat dilaksanakan di rumah, sekolah, perpustakaan, laboratorium, atau di tempat lain. Karakteristik dalam belajar kolaboratif adalah sebagai berikut:

a) Siswa belajar dalam satu kelompok dan memiliki rasa ketergantungan dalam proses belajar, penyelesaian tugas kelompok mengharuskan semua anggota bekerja bersama.

b) Interaksi intensif secara tatap muka antar anggota kelompok.

c) Masing-masing siswa bertanggung jawab terhadap tugas yang telah disepakati.

d) Siswa harus belajar dan memiliki ketrampilan komunikasi interpesonal.

e) Peran guru sebagai mediator.

f) Adanya sharing pengetahuan dan interaksi antara guru dan siswa, atau siswa dan siswa.

g) pengelompokkan secara heterogen.

Adapun kelebihan dan kekurangannya adalah sebagai berikut:

1) Kelebihan

a. Siswa belajar bermusyawarah

b. Siswa belajar menghargai pendapat orang lain

c. Dapat mengembangkan cara berpikir kritis dan rasional

d. Dapat memupuk rasa kerja sama

e. Adanya persaingan yang sehat

2) Kelemahan

a. Pendapat serta pertanyaan siswa dapat menyimpang dari pokok persoalan.

b. Membutuhkan waktu cukup banyak.

c. Adanya sifat-sifat pribadi yang ingin menonjolkan diri atau sebaliknya yang lemah merasa rendah diri dan selalu tergantung pada orang lain.

d. Kebulatan atau kesimpulan bahan kadang sukar dicapai.

Menurut Syah (2004:141), mendefinisikan prestasi belajar sebagai tingkat keberhasilan siswa dalam mencapai tujuan yang ditetapkan dalam sebuah program. Menurut 
Djaali (2013:108) menyatakan suatu prestasi atau achievement berkaitan erat dengan harapan (expextation) yang terbentuk melalui belajar dalam lingkungannya, sedangkan harapan selalu mengandung standar keunggulan (standart of exellent). Menurut Tu'u (2004:75) menyatakan prestasi merupakan hasil yang dicapai seseorang ketika mengerjakan tugas atau kegiatan tertentu. Prestasi belajar adalah penguasaan pengetahuan atau keterampilan yang dikembangkan oleh mata pelajaran yang lazimnya ditunjukkan dengan nilai tes atau angka nilai yang diberikan guru. Menurut Armstrong (2006:32) menyatakan bahwa Wacana Prestasi Akademik memandang tujuan pendidikan semata-mata untuk mendukung, mendorong, dan memfasilitasi kemampuan siswa meraih nilai tinggi dan nilai tes standar dalam pelajaran sekolah, terutama pelajaran-pelajaran yang termasuk bagian inti kurikulum.

Dari beberapa uraian di atas dapat disimpulkan bahwa prestasi belajar adalah hasil yang dicapai mahasiswa setelah melalui beberapa proses pembelajaran dari penguasaan pengetahuan mahasiswa oleh mata kuliah yang lazimnya ditunjukkan dengan nilai tes atau angka nilai yang diberikan dosen.

\section{Preatasi Belajar}

Menurut Syah (2004:141), mendefinisikan prestasi belajar sebagai tingkat keberhasilan siswa dalam mencapai tujuan yang ditetapkan dalam sebuah program. Menurut Djaali (2013:108) menyatakan suatu prestasi atau achievement berkaitan erat dengan harapan (expextation) yang terbentuk melalui belajar dalam lingkungannya, sedangkan harapan selalu mengandung standar keunggulan (standart of exellent). Menurut Tu'u (2004:75) menyatakan prestasi merupakan hasil yang dicapai seseorang ketika mengerjakan tugas atau kegiatan tertentu. Prestasi belajar adalah penguasaan pengetahuan atau keterampilan yang dikembangkan oleh mata pelajaran yang lazimnya ditunjukkan dengan nilai tes atau angka nilai yang diberikan guru. Menurut Armstrong (2006:32) menyatakan bahwa Wacana Prestasi Akademik memandang tujuan pendidikan semata-mata untuk mendukung, mendorong, dan memfasilitasi kemampuan siswa meraih nilai tinggi dan nilai tes standar dalam pelajaran sekolah, terutama pelajaran-pelajaran yang termasuk bagian inti kurikulum.

Dari beberapa uraian di atas dapat disimpulkan bahwa prestasi belajar adalah hasil yang dicapai mahasiswa setelah melalui beberapa proses pembelajaran dari penguasaan pengetahuan mahasiswa oleh mata kuliah yang lazimnya ditunjukkan dengan nilai tes atau angka nilai yang diberikan dosen. Dalam penelitian ini prestasi belajar adalah hasil belajar yang dicapai mahasiswa dalam proses belajar setelah menempuh seluruh mata kuliah akuntansi yang diprogram dalam semester yang telah diselesaikan.

\section{METODE PENELITIAN}

\section{Jenis Penelitian}

Berdasarkan sifat masalah dan tujuannya, penelitian akan dirancang dengan menggunakan Penelitian Tindakan Kelas (PTK). PTK yang akan dilaksanakan merupakan upaya ilmiah sistematis untuk mengembangkan praktik model pembelajaran Student Center Learning (SCL) dengan menggunakan metode Small Group Discussion dan Collaborative Learning melakukan berbagai tindakan praktis dalam pembelajaran terprogram. Secara umum kegiatan dalam satu siklus akan berawal dari tahap perencanaan, tindakan, observasi, dan diakhiri tahap refleksi. 


\section{Waktu, Tempat dan Subjek Penelitian}

Kegiatan penelitian ini dilaksanakan di IKIP PGRI Madiun Jalan Setiabudi No. 85 Madiun selama enam bulan, yaitu Maret s/d Oktober 2016. Subyek penelitian ini adalah 35 Mahasiswa kelas C semester III Program Studi Pendidikan Akuntansi.

\section{Data dan Sumber Data}

Sumber data yang terkait dengan penelitian meliputi: (1) data aktivitas; (2) subyek penelitian; dan (3) data dokumenter

\section{Teknik dan Instrumen Pengumpulan Data}

Lembar observasi, Hasil tes.

\section{Prosedur penelitian}

Prosedur penelitian merupakan tahapan-tahapan yang ditempuh dalam penelitian dari awal sampai akhir secara urut. Penelitian tindakan kelas ini akan dilaksanakan dalam dua siklus yang meliputi beberapa tahap kegiatan yaitu:

1. Perencanaan

Kegiatan yang dilakukan oleh peneliti pada tahap ini adalah:
a. Menyusun RPS dan RPP
b. Merumuskan masalah
c. Mengembangkan bahan ajar
d. Memilih dan menyiapkan media pembelajaran.

2. Tindakan

Melaksanakan pembelajaran dengan metode Small Group Discussion dan Collaborative Learning untuk meningkatkan prestasi belajar mahasiswa pendidikan akuntansi IKIP PGRI Madiun oleh dosen.

3. Observasi

Peneliti melakukan pengamatan untuk mengidentifikasi kendala-kendala dan proses implementasi pembelajaran Small Group Discussion dan Collaborative Learning yang dihadapi mahasiswa maupun dosen selama tindakan pembelajaran.

4. Refleksi

Refleksi dilakukan untuk menganalisis hasil tindakan agar dapat memperbaiki tindakan berikutnya. Prosedur penelitian yang digunakan adalah model PTK Mcel Kemmis dan Mc Taggart yang dapat digambarkan sebagai berikut: 


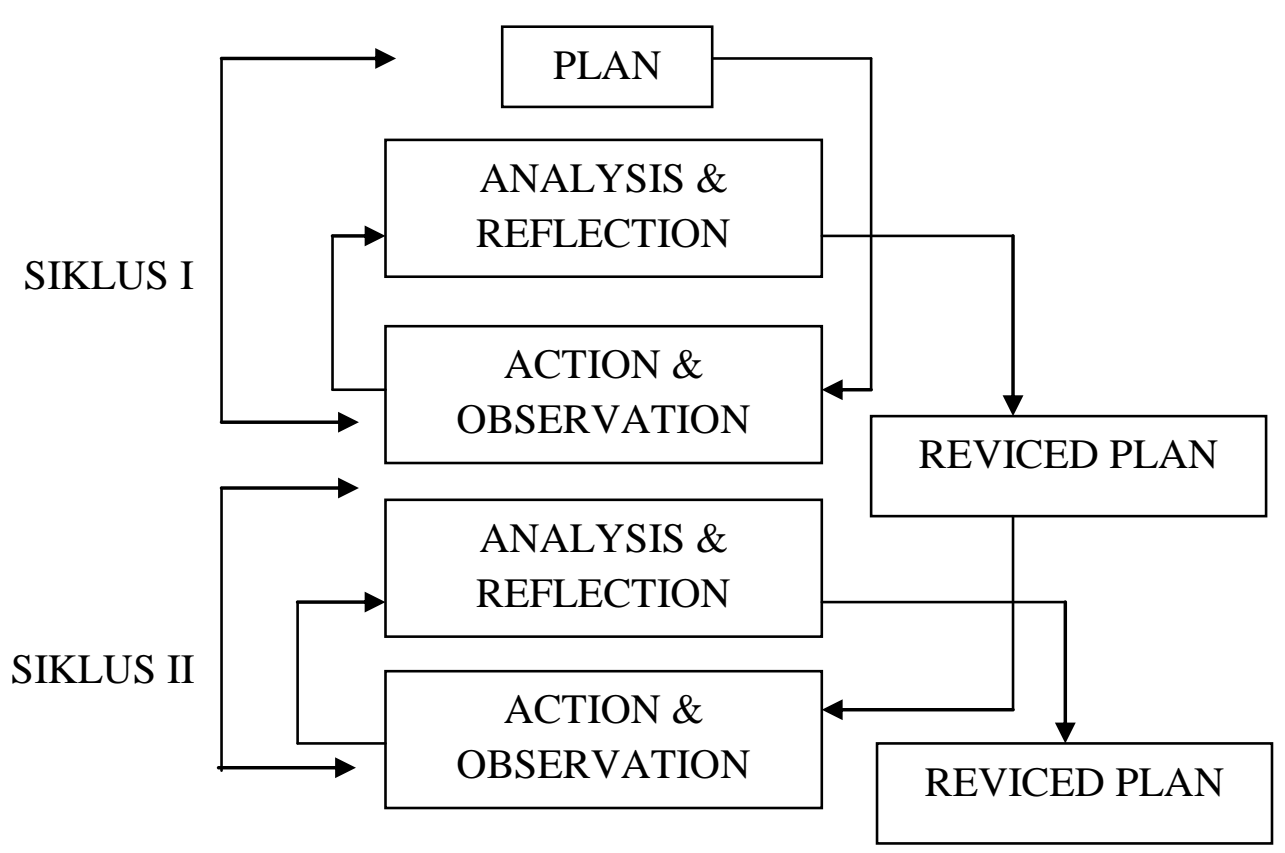

Gambar 3.1 Siklus Penelitian Tindakan Kelas

\section{Teknik Analisis Data}

Analisis dilakukan secara deskriptif kualitatif dengan menggunakan model Kemmis dan Taggart berdasar hasil observasi terhadap proses dan prestasi belajar, dengan langkah sebagai berikut:

1. Melakukan reduksi, yaitu mengecek dan mencatat kembali data-data yang telah terkumpul

2. Melakukan interpretasi, yaitu menafsirkan yang diwujudkan dalam bentuk pernyataan

3. Melakukan inferensi, yaitu menyimpulkan apakah dalam pembelajaran ini terjadi peningkatan motivasi berprestasi dan hasil belajar atau tidak (berdasar hasil observasi)

4. Tahap tindak lanjut, yaitu merumuskan langkah-langkah perbaikan untuk siklus berikutnya atau dalam pelaksanaan di lapangan setelah siklus berakhir berdasar inferensi yang telah ditetapkan

\section{KESIMPULAN DAN SARAN}

Penelitian tindakan kelas dilakukan untuk mengimplementasikan model pembelajaran Small Group Discussion dan Collaborative Learning kepada mahasiswa khususnya dalam meningkatkan prestasi belajar mahasiswa. Penelitian tindakan kelas dilakukan dalam mata kuliah hukum bisnis dengan model Kemmis dan Taggart melalui empat tahap yaitu: (1) perencanaan yaitu kelompok mahasiswa membuat makalah; (2) tindakan yaitu mengumpulkan tugas kelompok dan mempresentasikannya; (3) observasi yaitu mengamati presentasi makalah kelompok dan mengevaluasi makalah kelompok; dan (4) refleksi yaitu mahasiswa memperbaiki makalah kelompok dan menyerahkan kembali kepada peneliti.

Penelitian ini menemukan bahwa terjadi peningkatan prestasi belajar mahasiswa program studi pendidikan akuntansi IKIP PGRI Madiun dengan metode model pembelajaran Small Group Discussion Dan Collaborative Learning. Dibuktikan dengan meningkatnya prestasi belajar mahasiswa yaitu dengan nilai IPK A dan B dengan kategori lulus, serta telah terjadi peningkatan keterampilan mahasiswa dalam menulis makalah yaitu dengan memperbaiki 
makalah yang masih salah. Presentasi yang dilakukan mahasiswa juga semakin baik. Kompetisi yang sehat diantara kelompok mahasiswa menunjukkan kemajuan yang pesat dalam membuat makalah. Diharapkan penelitian selanjutnya bisa dilakukan pada mahasiswa yang sedang menempuh mata kuliah pengantar bisnis dan mata kuliah praktik akuntansi sehingga keterampilan mahasiswa dalam membuat makalah dan berdiskusi menyelesaikan studi kasus menjadi sangat baik serta prestasi belajar mahasiswa mengalami peningkatan.

\section{DAFTAR PUSTAKA}

Alma, Buchari. 2009. Guru Profesional Menguasai Metode dan Terampil Mengajar. Bandung: Alfabeta

Aqib, Zainal, dkk. 2008. Penelitian Tindakan Kelas untuk Guru SD, SLB dan TK. Bandung: CV.YramaWidya.

Arikunto, Suharsimi. 2010. Prosedur Penelitian Suatu Pendekatan Praktik. Jakarta: Rineka Cipta.

BSNP. 2006. Standar Kompetensi dan Kompetensi Dasar SD/MI. Jakarta : Badan Standar Nasional Pendidikan.

Djamarah, Syaiful Bahri. 2005. Guru dan Anak Didik dalam Interaksi Edukatif. Jakarta: Rineka Cipta.

Ekawarna. 2009. Penelitian Tindakan Kelas. Jakarta: GP Press.

Hanafiah, Nanang., Cucu Suhana. 2012. Konsep strategi pembelajaran. Bandung: PT Refika Aditama.

Hartono, Rudi. 2013. Ragam Model Mengajar yang Mudah Diterima Murid. Jogjakarta: DIVA Press

Haryati, Mimin. 2007. Model dan Teknik Penilaian pada Tingkat Satuan Pendidikan. Jakarta: GP Press.

Huda, Miftahul. 2013. Cooperative Learning. Yogyakarta: Pustaka Pelajar.

Jihad, Asep, Abdul Haris. 2013. Evaluasi Pembelajaran. Yogyakarta: Multi Pressindo.

Kemmis, Stephen and Robin McTaggart (eds). 1988. The Action Research Planner. Deakin University. Australia, Deakin University Press (3rd Edition).

Muslich, Masnur. 2011. Penilaian Berbasis Kelas dan Kompetensi. Bandung: Refika Aditama.

Tabrani, Rusyan dkk. 1994. Pendekatan dalam Proses Belajar Mengajar. Bandung: Remaja Rosdakarya.

Taniredja, Tukiran dkk. 2011. Model-Model Pembelajaran Inovatif. Bandung: Alfabeta. 
Trianto. 2007. Model - Model Pembelajaran Inovatif Berorientasi Konstruktivistik. Jakarta : Prestasi Pustaka.

Trianto. 2009. Panduan Penelitian Tindakan Kelas. Jakarta: Prestasi Pustaka.

Al-Migwar, Muhammad. 2006. Psikologi Remaja Petunjuk Bagi Guru Dan Orang Tua. Bandung : Pusaka Setia.

Armstrong, Thomas. 2006. The Best Schools. Virginia : ASCD.

Balsmeier and Peters. 2009. "Latar belakang keluarga atau Karakteristik Anak : Apa Menentukan SMA Sukses di Jerman?". Journal of Economics and Economic Education Research, Volume 10, Number 1, 2009. URL : http//search.proquest.com.

Baron, Robert A dan Donn Byrne. 2004. Psikologi Sosial Jilid 1 (Edisi Ke Sepuluh). Jakarta : Erlangga.

Djaali, 2013. Psikologi Pendidikan. Jakarta : Bumi Aksara.

Djamarah, Syaiful Bahri. 2008. Psikologi Belajar Edisi 2. Jakarta : Rineka Cipta.

Friday Glorianto. 2005. “Analisis Pengaruh Motivasi Mengikuti Pelatihan dan Peran kepemimpinan Terhadap Kinerja Karyawan Melalui Orientasi Pembelajaran (Studi Kasus pada Kantor Pelayanan Pajak Pekalongan)”. http://eprints.undip.ac.id/10279/1/2005MM4260.pdf.

Hamalik, Oemar. 2005. Kurikulum Dan Pembelajaran. Jakarta : PT Bumi Aksara.

Hurlock. 1980. Development Psychology A Life-Span Approach, Fifth Edition. McGraw-Hill, Inc.

IKIP PGRI MADIUN. 2015. Pedoman Penulisan Skripsi.

Jamaluddin Sawaji, Djabir Hamzah, dan Idrus Taba. 2010. "Pengambilan Keputusan Mahasiswa dalam Memilih Perguruan Tinggi Swasta Di Sulawesi Selatan". http://pasca.unhas.ac.id/jurnal.

Jonathan H. Westover, Ph.D. 2012. "Comparative International Differences in Intrinsic and Extrinsic Job Quality Characteristics and Worker Satisfaction, 1989-2005". International Journal of Business and Social Science Vol. 3 No. 7; April 2012.

Kaylene C. Williams and Caroline C. Williams. 2011. "Five key ingredients for improving student motivation". Research in Higher Education Journal.

Kusuma. 2009. Mengenal Penelitian Tindakan Kelas. Jakarta, PT. Indeks.

Ridwan. 2006. Belajar Mudah Penelitian Guru, Karyawan dan Peneliti Pemula. Bandung: Alfabeta. 
Riyanto, Yatim. 2007. Metode Penelitian Pendidikan Kualitatif dan Kuantitatif. Surabaya: Unesa University Press.

Sardiman. 2010. Interaksi \& Motivasi Belajar Mengajar. Jakarta : Rajawali Pers.

Slameto. 2010. Belajar \& Faktor-Faktor Yang Mempengaruhi. Yogyakarta : Rineka Cipta.

Sugiyono. 2010. Metode Penelitian Kuantitatif, Kualitatif Dan $R \&$ D. Bandung : Alfabeta.

Suyanto. 1997. Pedoman Pelaksanaan Penelitian Kelas. Jakarta, Dirjen Dikti. Wijaya

Syah, Muhibbin. 2005. Psikologi Pendidikan dengan Pendekatan Baru. Bandung : PT Remaja Rosdakarya.

Tu'u, Tulus. 2004. Peran Disiplin pada Perilaku dan Prestasi Siswa. Jakarta : Grasindo.

Uno, Hamzah B. 2009. Teori Motivasi \& Pengukurannya. Jakarta : Bumi Aksara. 